\title{
チャンレー型人工股関節の長期成績
}

\begin{tabular}{|c|c|c|c|c|}
\hline 谷 & $\square$ & 良 康・牧 & & 信 \\
\hline 濱 & 里 & 雄二郎 - 中 & 村 & \\
\hline 川 & 畑 & 直 也 - 山 & $\square$ & 幸 \\
\hline 福 & 嶺 & 紀 明 & & \\
\hline
\end{tabular}

\section{Follow-up Study of Long-term Results over 14 years of Charnley Type Total Hip Arthroplasty}

\author{
Yoshiyasu Taniguchi, Shinya Maki, Yujiro Hamasato, Makoto Nakamura, \\ Naoya Kawabata, Kouji Yamaguchi, and Noriaki Fukumine \\ Department of Orthopaedic Surgery, Kagoshima City Hospital, Kagoshima, Japan
}

\begin{abstract}
Fifty-three hips of 49 patients were available for the study.
All of them had received clinical and radiological examinations twice annually or annually.

Their mean age at surgery was 57 years. The average postoperative period was 17.8 years, ranging from 14 to 26.2 years. Diagnosis at the time of surgery was 48 cases of osteoarthritis, 2 cases of rheumatoid arthritis, 2 cases of osteonecrosis of the femoral head, and 1 case of femoral neck fracture. Clinical results were evaluated using the JOA scoring system; radiological evaluation was performed by Charnley's method on the acetabular side, and Nagaya's method on the femoral side. The preoperative JOA score of 44 points improved to 84.3 points after one year postoperatively, remained at 77.5 points after 15 years and at 78.5 points for over 20 years.

Radiologically, G4 showing migration of the socket was recognized in $10 \%$ of the patients after 10 years and in $17 \%$ after 20 years. Stage 4 showing subsidence of the stem was recognized in $4 \%$ after 10 years and in more than $4 \%$ in 15 years. Revision surgery was performed on 9 hips.
\end{abstract}

Key words : Charnley Type Total Hip Arthroplasty (チャンレー型人工股関節置換術), Clear Zone : （臼蓋側及びステム側の C.Z.), Loosening：（ゆるみ）

\section{は じめに}

1974 年から変形性股関節症, 慢性関節リュウマチ, 大腿骨骨頭壊死症の末期症例に対してチャンレー式人 工股関節設置術を行ってきた。その中で 1986 年まで の症例（14 年以上の経過例）の成績を検討したので 結果を報告する.

\section{対 象 症 例}

1974 年から 1986 年までに置換術が行われ，定期的に 検診された，49 例 53 関節である. 内，男性 7 例 7 関 節，女性 42 例 46 関節であり，この内，両側手術例は 4 例 8 関節である. 手術時年令は平均 57 才, 術後経 過年数は 14 年以上最長 26.2 年で, 20 年以上経過し たもの 11 例 11 関節，平均 17.8 年である。（表 1) 対象疾患, 变形性股関節症 44 例 48 関節, 慢性関節リ二 


\section{対象症例（表 1)}

1974 年から 1986 年までにチャンレー式人工股関

節置換術が行われ，定期的に検診された症例. 49 例 53 関節

男性 7 例 7 関節

女性 42 例 46 関節

$*$ 両側手術例 4 例 8 関節

手術時平均年令 57.09 才（46才から 79 才） 手術経過年数 平均 17.8 年 (14 年以上最長 26.2 年)
対象疾患（表 2）

\begin{tabular}{|crc|}
\hline \hline 変形性股関節症 & 44 例 & 48 関節 \\
慢性関節リュ ウマチ & 2 例 & 2 関節 \\
特発性大腿骨骨頭壊死 & 2 例 & 2 関節 \\
大腿骨頚部骨折 & 1 例 & 1 関節 \\
総計 & 49 例 & 53 関節 \\
$*$ 変形性股関節症 & 44 例 & 48 関節 \\
片側変股症 & 24 例 & 24 関節 \\
両側変股症 & 16 例 & 16 関節 (片側 THA) \\
& 4 例 & 8 関節 (両側 THA) \\
\hline
\end{tabular}

$\begin{array}{lcccccc} & \text { 術前点数 } & \text { 術後 1 年 } & \text { 5年 } & \text { 10年 } & \text { 15年 } & 20 \text { 年 } \\ \text { ADL } & 10.2 & 15.1 & 14.8 & 14.1 & 13.2 & 12.7 \\ \text { ROM } & 12 & 15.9 & 16.4 & 16.3 & 16 & 14.8 \\ \text { 歩行 } & 8.9 & 16.8 & 15.4 & 14.5 & 13.7 & 14.5 \\ \text { 庝痛 } & 12.9 & 36.5 & 36.1 & 36.5 & 34.6 & 36.4\end{array}$

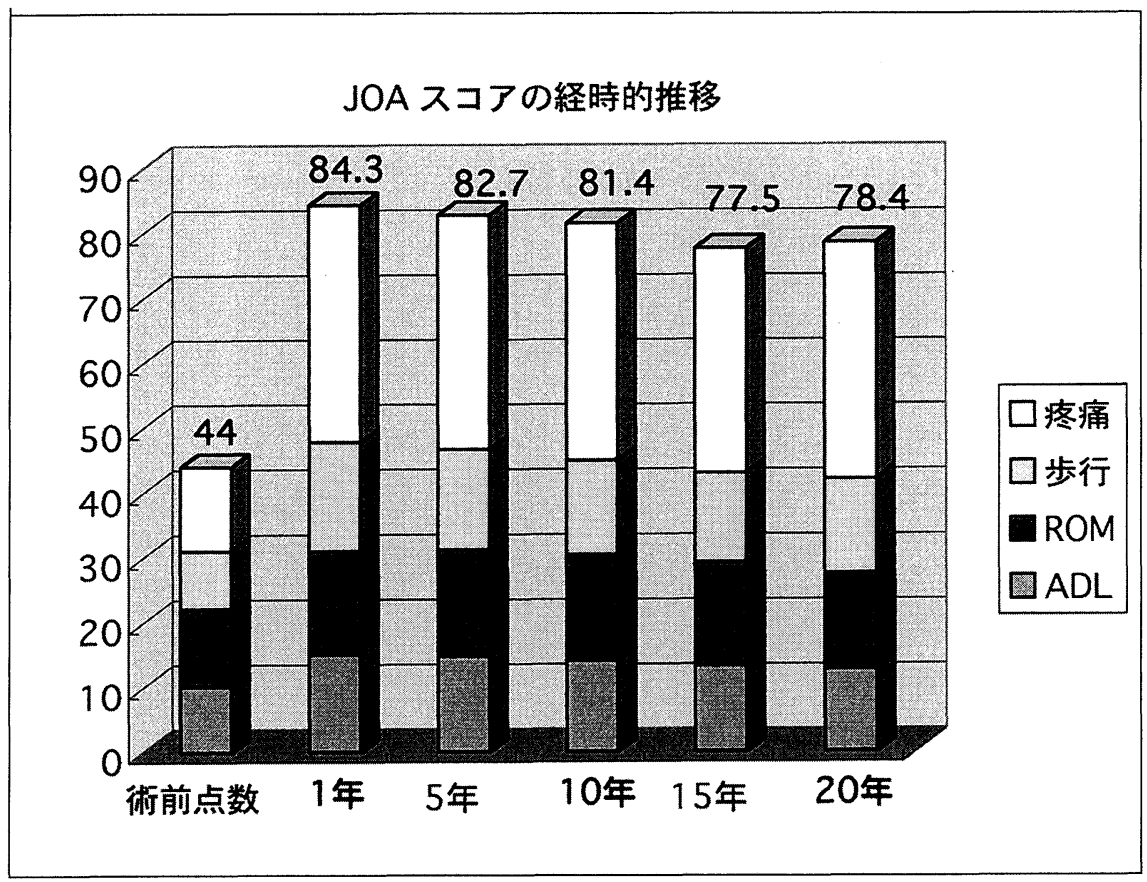

図 1 術後 1 年で JOA スコアは著明に改善され, 殊に疼痛の改善が著しい.

ウマチ，特発生大腿骨骨頭壊死がそれぞれ 2 例 2 関節, 頚部骨折 1 例 1 関節であった。ささらに変形性股関節症 では, 片側変股症 24 例 24 関節で, 両側変股症では
16 例 16 関節に片側のみ置換術が行われ，両側置換術 は 4 例 8 関節であった.（表 2 ） 


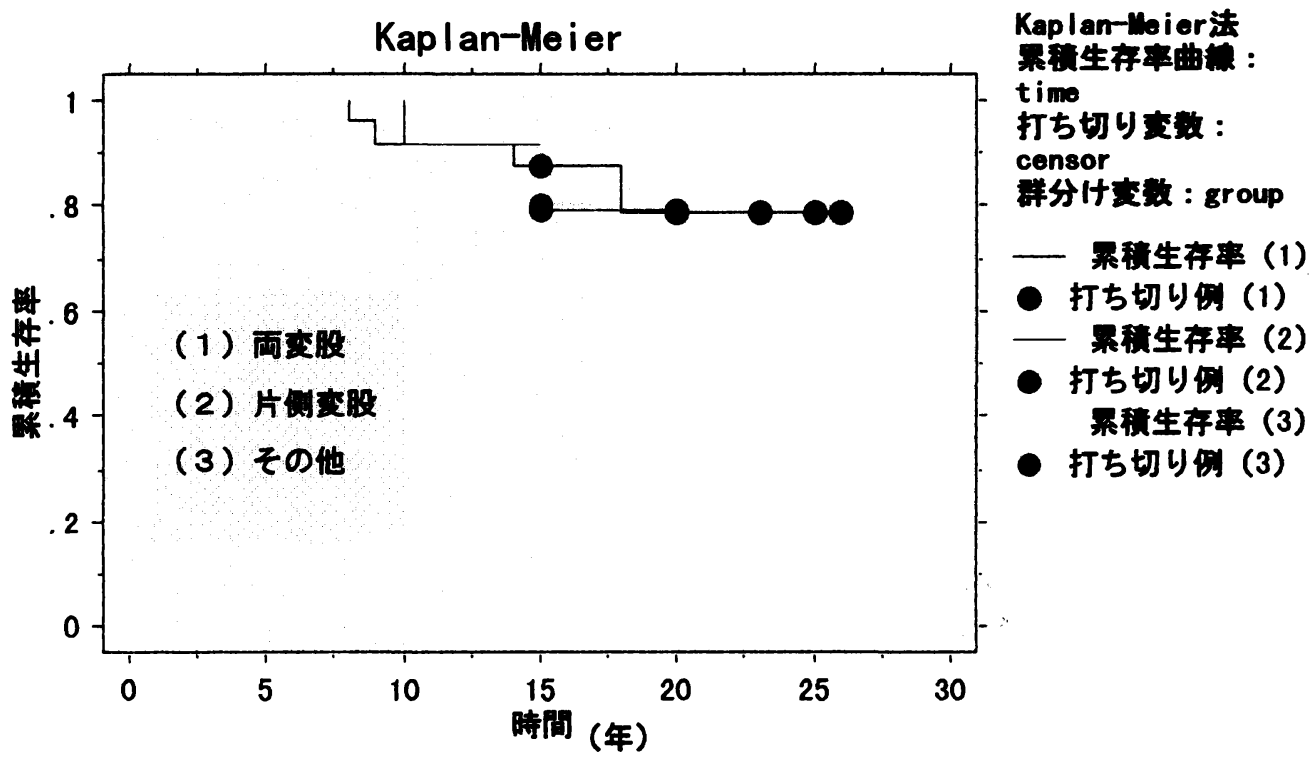

図 2 累積生存曲線 両側変股症, 片側变股症ともに $80 \%$ の生存率を示している.

評価法

臨床像の評価は日整会股関節機能判定基準に従って 判定, X線評価は臼蓋側ではチャンレーの評価法 ${ }^{1), 2)}$ による Grade 1 から 4 , 大腿骨側は長屋の評価法 ${ }^{6)}$ による Stage 0 から 4 に従った。

ソケットの摩耗計測については, レ線写真を用いて, 原口等の方法 ${ }^{3)}$ で線摩耗量を計測した。

\section{成綘}

臨床成績では, 術前の総合平均点数 44 点が術後 1 年で 84.3 点に改善されており, 項目別では, 術前の 疼痛 12.9 点が 36.5 点と有意に改善された，総合点数 は術後 10 年, 15 年と緩やかに下降しているが, 20 年 以降は 11 例の症例が検診されていて, 平均総合点数 は78.4点であった。（図 1)

臼蓋側のX線所見では, 術後 1 年で Grade 1 が 68 $\%$ に対し Grade 2, 即ち Clear Zone（以下 CZ と略

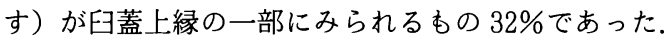
術後 5 年で Grade $3 \quad 5$ 例 10\%が現れ，10 年後には $10 \%$ が Grade 4 に進行し， 20 年以上になると $17 \%$ が Grade 4 に進行していた.

大腿骨側では, 術後 10 年でステムの移動, 沈下な
どを示す Stage 4 が 2 例 $4 \%$ であり，15 年後では 1 例 $2 \%$ と壬蓋側に比べるとゆるみはるかに少ない，特 殊例としてステムに折損が 1 例, 彎曲が 1 例発生した。 ソケットの摩耗は原口等に従ってレ線写真を用いて線 摩耗量を計測した。術後 15 年から 20 年の間に 3 ミリ 以上の著明な摩耗を示した 6 例， $12 \%$ があるが，計測 結果は年平均 0.02 ミリ之, 文献的に比較しても, 少 ない傾向であった。

術後の成績をカプランーマイヤーの累積生存率でみ ると, 両側変股症, 片側変股症の間に有意の差が見ら れず, 20 年以降も $80 \%$ に到る生存率を示している. (図 2 )

\section{症例の提示}

（1） 53 才，女性，左変形性股関節症 初診時 JOA スコア 45 点, 術後 19 年経過で 82 点, $\mathrm{X}$ 線所見では，且蓋側 Grade 2，ステム側 Stage 2 でンケット摩耗は見られない，(図 3 )

（2） 63 才，女性，14 年経過でソケットの著明な摩 耗と大腿骨側のオステオライシスが進行し，再置換術 が行われた.（図 4) 


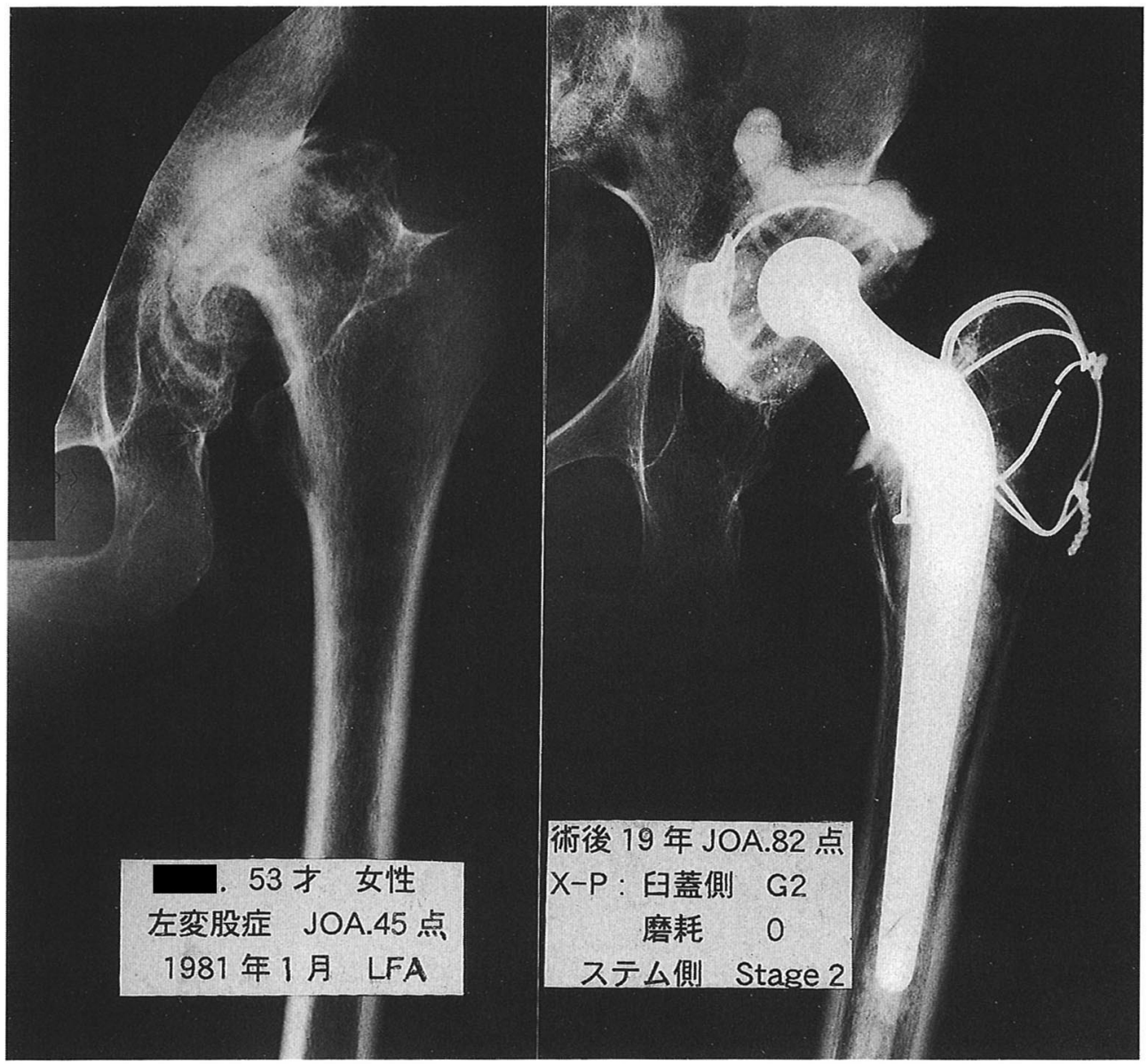

図 3 左変股症で術後 19 年経過. 臼蓋側 G2, ソケットの摩耗は見られない. ステム側 Stage 2.

\section{術後合併症}

Aseptic Loosening のため再置換術を行ったもの 9 例 9 関節, $17 \%$ で, 時期は術後 8 年から 15 年の間で あった。オステオライシス 3 例 $6 \%$, ソケットの著明 な摩耗 6 例 $12 \%$, 反復脱臼 2 例 $4 \%$, 特殊例として 金属疲労によるシステム折損 1 例, 彎曲 1 例が見られ た.

\section{考察}

人工股関節のゆるみ, ソケットの摩耗は術後長期経 過の中で避けられない合併症である。ことに骨セメン トの劣化 ${ }^{4)}$ は, 老化に伴う骨皮質の脆弱化と相まって ゆるみの原因となる，さらにオステオライシス, 術後
の感染，遅発性感染，手術手技など人工股関節の長期 維持の為には多くの問題をかかえている． 砂原 ${ }^{5}$ 等は ソケット設置法とレ線上成績悪化例との関連では, ソ ケットの設置位置が高いこと，はみだし，臼蓋上縁で のセメント充填の量が多いこと等に有意に悪化の傾向 が見られるという．材質の問題として HDP の耐摩耗 性, チャンレー ${ }^{1)}$ はこの問題解決の為にステムへッド サイズ径を 22.5 ミリとして低トルク，低摩擦による HDP の耐摩耗性を図った, 即 Low Friction Arthroplasty の由縁である。さらに金属強度の問題 が有り，現に金属疲労によるステム折損の症例之彎曲 した症例を経験した．位走差顕微鏡検査で金属疲労が 証明されている。 


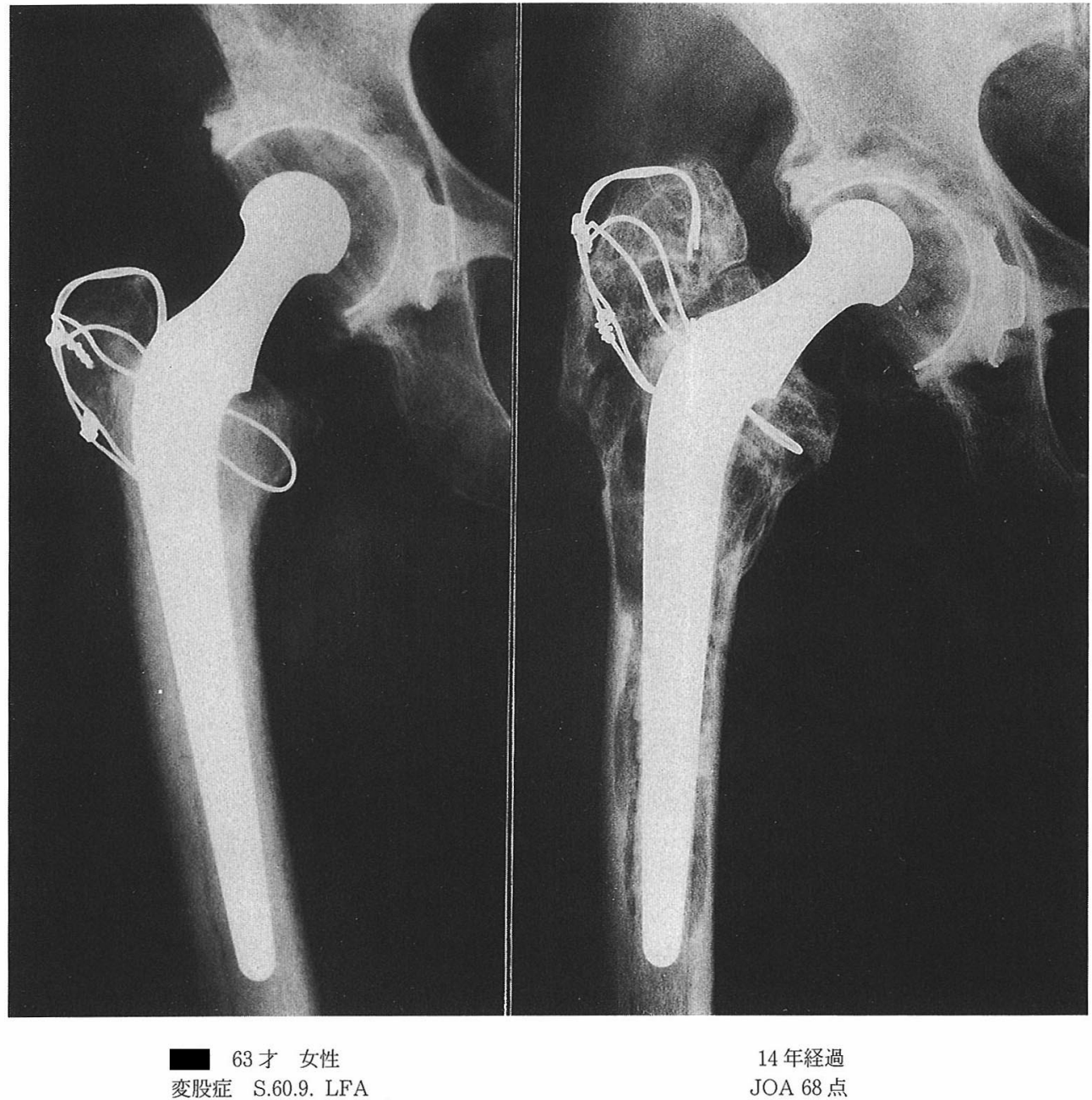

図4 術後 14 年でソケットのゆるみ, 摩耗, 大腿骨のオステオライシス, ステムのゆるみが生じている. 再置換術を行った.

\section{ま と め}

（1）チャンレー式人工股関節置換術後，14 年以上 経過した症例で， 6 力月ないし 1 年間隔で定期検診を 受けてきた症例 49 例 53 関節の術後成績を評価した.

（2）日整会股関節機能判定基準，総合成績では，15 年経過で平均 77.5 点, 20 年を経過した 11 例 11 関節 では平均 78.4 点を維持していた. さらに項目別に分 析すると, 術後疼痛の改善が著明であった。

（3）レ線所見, 臼蓋側では術後経過中, すでに 5 年
で 5 関節 (10\%) にチャンレー評価の Grade 3 が現 れ，10 年経過で $10 \%$ がG 4 へ進行した。 大腿骨側で は術後 15 年までに 2 例 $4 \%$ のステム移動, 沈下がみ られた。

(4) 再置換術例は 9 例 9 関節 17\%で, 術後 8 年目 から 15 年の間に全て行われた.

（5）オステォライシスは 3 例 $6 \%$ であり, 反復脱臼 2 例, ソケット $3 \mathrm{~mm}$ 以上の著明な摩耗を示したむ の 6 例 12\%, 特殊例としてステムの折損, 彎曲を各 1 例経験した. 


\section{参考文献}

1) Charnley, J.: Low Friction Arthroplasty of the HipTheory and Practice-. Springer-Verlag. Berlin, 1979.

2) DeLee, J. G. and Charnley, J.: Radiological Demarcation of Cemented Sockets in Total Hip Replacement. Clin. Orthop., 121: 20-32, 1976.

3）原口圭司ほか：バイオセラム型セメント人工股関節の ポリエチレン摩耗. 日本人工関節学会誌, $29: 259-260$,
1999.

4）奥村秀雄：チャンレー人工股関節置換術 20 年の到達 点. 日整会誌, $65 ： 975-985,1991$.

5）砂原伸彦ほか：10 年以上経過した Charnley 型人工股 関節置換術の成績. 整形外科之災害外科, 41：601-603, 1992.

6）宇野雅久：全人工股関節置換術後の透亮像の経時的観 察. 日整会誌, $55: 543-562,1981$. 